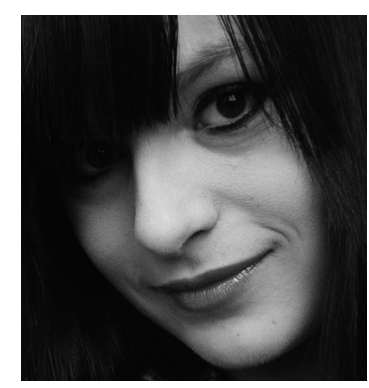

Izabela Poniatowska

Izabela Poniatowska - doktorantka w Zakładzie Literatury i Kultury II Połowy XIX wieku Uniwersytetu Warszawskiego. Zainteresowania naukowe obejmują przede wszystkim polską literaturę popularną drugiej połowy XIX wieku i jej związki z formacją modernistyczną, a także szeroko pojętą kulturę popularną. Wybrane artykuły: Powiedzieć zobaczone - zobaczyć powiedziane. Motywy fotograficzne w "Szachinszachu" Ryszarda Kapuścińskiego; Marzyciele czyli zerwane nici porozumienia ze światem („Marzyciel" Wt. St. Reymonta, "Ze wspomnień cyklisty" B. Prusa, "Marzyciele" K. Hamsuna); Narracja jako struktura fotograficzna w "Pleśni świata" i "Cieniach" Bolesława Prusa. 


\section{Grabiński popularny?}

zy pisarz zapomniany może być pisarzem popularnym? Czy pisarz dziś właściwie nieznany, a na pewno niedostatecznie rozumiany za swojego życia ${ }^{1}$ może być uznany za twórcę popularnego? Te dwa pytania niewątpliwie pojawić się muszą przy próbie zestawienia Stefana Grabińskiego z kategorią „popularnego pisarza”.

Odpowiedź na pierwsze z postawionych wyżej pytań jest prosta: oczywiście, tak. „Popularność” to kategoria bardzo mocno związana z aktualnością. Z historii literatury zaś ocalone zostaje niewiele, czego dowodem chociażby powszechna dziś nieznajomość poza kręgami akademickimi nazwisk pisarzy niezwykle poczytnych na przełomie XIX i XX wieku (np. Artura Gruszeckiego, Teodora Jeske-Choińskiego, Józefy Kisielnickiej czy Emmy Dmochowskiej). Istotny byłby tu problem kanonu, o którym tak pisze Inga Iwasiów: „Po pierwsze, kanon jako zbiór arcydzieł, obowiązkowa lista lektur, szkolny podręcznik, encyklopedia. Po drugie, kanon interpretacji, sposoby lektury, wiodące odczytania, uprzywilejowane metodologie. Po trzecie wreszcie - kanon jako statystyka czytelnictwa, indywidualne wybory, sezonowe mody, nieformalne obiegi”’. Grabiński, jak mi się wydaje, nie daje się łatwo wpasować $\mathrm{w}$ żaden $\mathrm{z}$ trzech zaproponowanych przez Iwasiów kręgów kanonu (tym bardziej że „kanon” w rozumieniu trzecim niezwykle trudno zbadać w odniesieniu do tekstów z początku XX wieku). Mam wrażenie, że wynika to nie tylko z wielokrotnie przez badaczy podkreślanej osobności twórczej autora Kochanki Szamoty, ale przede wszystkim z niedostrzegania możliwości funkcjonowania pisarza właściwie dziś poza kręgami akademickimi nieznanego $\mathrm{w}$ „osoczu” prężnie przecież rozwijającej się na ziemiach polskich już od przełomu XIX i XX wieku kultury popularnej.

Inna sprawa, że o przynależności danego twórcy do obiegu popularnego w drugiej połowie XIX i na początku XX wieku powinny przesądzać przede wszystkim analizy jego tekstów: nie ma bowiem wystarczających danych dotyczących chociażby preferencji ówczesnych czytelników, często trudno ustalić rzeczywistą liczbę wydań danego tekstu; za powiększającą się w związku z rozwojem ruchu wydawniczego liczbą powieści i zbiorów opowiadań nie nadążała również krytyka, która bardzo chętnie do szuflady z etykietką „piśmiennictwa dla kucharek" wrzucała twórczość pisarzy niekoniecznie mieszczących się

\footnotetext{
1 Choć warto pamiętać, że miał Grabiński swoje chwile sławy, związane na przykład z wydaniem zbiorów Na wzgórzu róż i Demon ruchu (TLSG, s. 78-81).

2 I. Iwasiów, Wokół pojęć: kanon, homoerotyzm, historia literatury, „Katedra” 2001, nr 1, s. 101.

3 J. Kolbuszewski, Od Pigalle po Kresy. Krajobrazy literatury popularnej, Wrocław 1994, s. 10.
} 


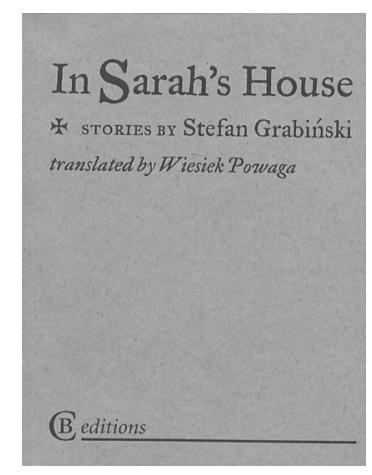

S. Grabiński, In Sarah's

House, CB Editions, London 2008 w jednym obiegu literackim (vide rozważania Stanisława Brzozowskiego na temat „powieści-flądry”" ${ }^{\prime 4}$. Dlatego też ustalenie, czym jest literatura popularna i kto może być uznany za pisarza popularnego, w znacznej mierze zależy dziś od historyków literatury drugiej połowy XIX i początku XX wieku.

Odpowiedź na drugie z postawionych na początku pytań - czy pisarz niedostatecznie rozumiany przez swoich współczesnych może zostać uznany za twórcę popularnego - nie jest już tak oczywista i zależy w gruncie rzeczy od przyjętej definicji tekstu popularnego. Mnie najbliższa jest definicja Tadeusza Żabskiego, według którego literatura popularna jest „dziedziną twórczości literackiej, obejmującą utwory przeznaczone dla szerokiego kręgu czytelników, nastawione na realizację ich potrzeb osobowościowych, na dostarczenie im rozrywki i silnych przeżyć emocjonalnych"s (co zwykle idzie w parze z nieprzychylnym nastawieniem krytyków wobec tych tekstów); nie neguję jednak badania „popularności” właśnie za pomocą „poczytności”. Gdyby posługiwać się tylko kryteriami zewnątrztekstowymi (jakimi niewątpliwie są wspomniane badania czytelnictwa), Stefan Grabiński nie mógłby w żadnym razie być uznany za twórcę popularnego. Jednak badania twórczości autora Salamandry pod kątem używanych przez niego strategii twórczych - a mam tu na myśli przede wszystkim stosowanie klisz tekstów popularnych - pokazuje, że „Grabiński popularny” istnieje.

Trzeba pamiętać, że poza kryteriami zewnątrztekstowymi mamy również pewne - wymienione już w definicji Żabskiego - wewnątrztekstowe przesłanki, które pozwalają powiązać twórczość danego pisarza z literaturą popularną. Jedną z takich przesłanek (zwykle nie mówi się o niej wprost) jest decyzja historyków literatury, których zadaniem jest przecież m.in. odpowiednie zakwalifikowanie - jakkolwiek w większości wypadków z zastrzeżeniami, dyskusjami i ścieraniem się stanowisk interpretacyjnych - badanych dzieł. Hasło Grabiński Stefan figuruje w Stowniku literatury popularnej, podobnie jak hasło Żuławski Je$r z y$; i jest to decyzja arbitralna redaktorów Stownika..., którzy równie arbitralnie pominęli w swojej publikacji chociażby pisarstwo Antoniego Langego. Po raz kolejny: „Grabiński popularny”, przynajmniej w świadomości historyków literatury, istnieje. O autorze Cienia Bafometa Artur Hutnikiewicz pisał oględnie, że „nie był pisarzem popularnym w obiegowym tego słowa znaczeniu" (TLSG, s. 58). Dlaczego więc zdecydowałam się pójść tropem takiej - „popularnej” - interpretacji twórczości Grabińskiego? Mam bowiem wrażenie, że istnieją gatunki literackie szczególnie podatne na narracje popularne. Bez wątpienia należy do nich opowiadanie/powieść fantastyczna czy opowiadanie/powieść grozy - łatwo się schematyzujące lub wręcz stereotypizujące. Wspomniana łatwość w uleganiu stereotypom powoduje, że zarówno Grabiński, jak i chociażby jego (niemalże) rówieśnik Lovecraft czy pisarze mniej znani lub wręcz drugorzędni, budując nastrój w obrębie swoich tekstowych światów, w zasadzie posługują się tymi samymi chwytami. Podatność na stereotyp może być tym jaskrawsza, że fantastyka w wydaniu stricte popularnym jeszcze nie istniała - w przeciwieństwie do powieści historycznej czy tekstów o tematyce współczesnej, które na początku XX wieku miały już swoje odmiany popularne; twórczość fantastyczna dopiero swoje konwencje wypracowywała, co było tym trudniejsze, że Grabiński „tworzył w epoce, w któ-

${ }^{4}$ S. Brzozowski, Kultura i życie, [w:] Polska krytyka literacka (1800-1918). Materiały, t. 4, red. J. Z. Jakubowski et al., Warszawa 1959.

${ }_{5}$ T. Żabski, Literatura popularna, [hasło w:] Słownik literatury popularnej [dalej: SLP], red. T. Żabski, Wrocław 2006, s. 310. 
rej literatura nastawiona była programowo na codzienność i «szarego człowieka»" (DO, s. 16).Zbigniew Jarosiński pisze, że w literaturze popularnej dwudziestolecia międzywojennego „norma gatunkowa staje się głównym pośrednikiem między utworem a jego odbiorcą. Wtajemniczenie genologiczne wypiera ten typ wtajemniczenia, którego podstawą było obcowanie z innymi, wcześniejszymi dokonaniami pisarza, deklaracjami programowymi, wiadomościami o jego pozaliterackich rolach społecznych"6. Postrzeganie tekstu przez pryzmat normy genologicznej staje się szczególnie istotne w wypadku utworów o tematyce fantastycznej: dopiero znajomość konwencji pozwala czytelnikowi uniknąć dezorientacji w świecie tak innym od codziennego.

Oczywiście, strategie, które mają na celu przyciągnięcie odbiorcy do tekstu, stosowane są z powodzeniem także przez autorów arcydzieł. Osmoza między obiegiem wysokim a popularnym ${ }^{7}$ funkcjonuje, a szczególnie żywa była na początku XX wieku i - jak stwierdza Erazm Kuźma - to między innymi rozwój literatury popularnej odgrywał istotną rolę w przemianach literatury wysokiej ${ }^{8}$. Paradoksalnie, wykorzystywanie chwytów i schematów tekstu popularnego staje się dla twórców nurtu wysokoartystycznego polem eksperymentów, zwierciadłem, w którym przegląda się wybitna indywidualność pisarska. Tak było chociażby w wypadku Dziejów grzechu Stefana Żeromskiego.

Zabiegiem niewątpliwie związanym z użyciem strategii, którymi posługuje się literatura popularna, jest swoiście zinterpretowany problem erotyki. Grabiński niezwykle chętnie redukuje wątek miłosny jedynie do fascynacji erotycznej, romans zawężając do motywu spotkania i zbliżenia. Podobnie jak Pitigrilli, tworzący w tym samym czasie autor poczytnych tekstów z pogranicza erotyki i pornografii (choć tłumaczony na język polski dopiero w latach 30. XX wieku'), Grabiński za pomocą przyjętej formuły romansu kreśli wizję samotności człowieka w świecie, w którym intymność nie jest porozumieniem dusz, lecz jedynie wciąż pozostawiającym niedosyt zetknięciem ciał. Tak dzieje się chociażby w opowiadaniu Kochanka Szamoty: w zawiązaniu akcji czytelnik dowiaduje się, że narrator, Jerzy Szamota, otrzymuje list od kochanej przez siebie kobiety, pomimo że jest „nieznanym jej zupełnie, skromnym wielbicielem z oddali, z którym jej nigdy przedtem nie łączyły towarzyskie stosunki, choćby przelotna znajomość" (N, s. 391). Choć zakończenie opowiadania pokazuje, że Szamota romansował z upiorem (lub upiorną projekcją własnej, rozstrojonej wyobraźni), to fabuła opiera się na opisie kolejnych schadzek, podczas których piękna kochanka nie mówi ani słowa: „cała zamknęła się [bowiem] w błędnym kole płci i tarza się w rozpasaniu, czołga w konwulsjach płci” (N, s. 404); można przecież czytać Grabińskiego także na tym pierwszym, elementarnym poziomie, jako „romans w dziwnych dekoracjach”. Ponieważ Stefan Grabiński jest jednym z prekursorów horroru literackiego w Polsce, erotyzm odgrywa w jego twórczości niezwykle istotną rolę; powinowactwo wątków erotycznych i elementów grozy to cecha charakterystyczna tego gatunku ${ }^{10}$. Zwłaszcza w wypadku opowiadań „wampirycznych” seks, poczucie zagrożenia i śmierć są nierozłączne: „związek z wampirem

${ }^{6}$ Z. Jarosiński, Literatura popularna a problemy historycznoliterackie, [w:] Formy literatury popularnej, red. A. Okopień-Sławińska, Wrocław 1973, s. 17.

7 A. Dec, Kilka uwag o powieści-flądrze na młodopolskim rynku czytelniczym, „Literatura i Kultura Popularna" 1992, z. 2/3, s. 68.

${ }^{8}$ E. Kuźma, Literatura popularna a literatura wysokoartystyczna, [hasło w:] SLP, s. 320-321.

${ }^{9}$ M. Bujnicka, Pitigrilli, [hasło w:] SLP, s. 434.

10 K. Walc, Horror, [hasło w:] SLP, s. 225. 
jest związkiem erotycznym, w którym kochankowie stają się ofiarami niszczącej namiętności”"11 - pisze w kontekście tekstów Grabińskiego Barbara Zwolińska.

Podobnie jak współcześni mu twórcy, Stefan Grabiński fascynuje się również zdobyczami techniki; tę fascynację widać zwłaszcza w zbiorze Demon ruchu. Bohaterowie opowiadań z tego cyklu mają obsesję na punkcie pędu, prędkości, możliwości ścigania czasu i zagarniania przestrzeni, jakie stwarza poruszanie się koleją. Boroń, bohater Smolucha, interesuje się przede wszystkim ruchem jako takim - i nie jest bohaterem odosobnionym u Grabińskiego, który „wirus” ruchu „zaszczepia” przede wszystkim ludziom z pozoru bardzo przeciętnym. Nowoczesność, której literackim emblematem niewątpliwie na przełomie XIX i XX wieku był pociąg, to w twórczości autora Salamandry coś dostępnego dla wszystkich, więcej nawet - coś szczególnie bliskiego tym, którymi pogardza świat. Takie spojrzenie na nowoczesność jest charakterystyczne dla bohaterów prozy popularnej: na przykład robotnicy z Cygarniczki Artura Gruszeckiego w święta chadzają do kinematografu, choć na co dzień pracują w warunkach uwłaczających godności ludzkiej ${ }^{12}$, a przeciętne miasteczko Ryszwil z opowiadania Gustawa Daniłowskiego staje się świadkiem „niesamowitego” wykolejenia pociągu pozbawionego maszynisty ${ }^{13}$.

Kolejnym obszarem artystycznych zainteresowań Grabińskiego są bez wątpienia tajemnice jaźni. W jego tekstach pojawiają się m.in.: autosugestia (N, s. 61), telepatia (N, s. 69), hipnoskop (przyrząd do hipnotyzowania, którego konstrukcją notabene zajmował się również Julian Ochorowicz - N, s. 444) - to również wiąże twórczość pisarza z duchem epoki ${ }^{14}$; w drugiej połowie XIX wieku fascynacja „ciemną”, nieodgadnioną stroną rzeczywistości, której wyrazem stały się badania nad spirytyzmem i mediumizmem, rosła przecież równolegle do krzepnięcia scjentyzmu. „Literacka kariera dwóch figur semantycznych - Sherlocka Holmesa i prof. Geista - jednoznacznie wskazują na nieograniczoną wiarę w potęgę rozu$\mathrm{mu}$, ale już popularność mediumizmu i orientalizm podają tę wizję stulecia w wątpliwość"15 - czytamy w eseju Dzikusy Bettelheima. W twórczości autora Salamandry znaleźć można i Sherlocków - poszukujących prawidłowości w świecie, któremu nie chcą odmówić logiki - i Geistów - niestrudzonych badaczy tajemnic, często zmuszonych przyznać się do kapitulacji w obliczu obcowania z czymś, co dotychczas wydawało się niemożliwe; tak mówi narrator noweli Fałszywy alarm o „śledztwach” prowadzonych przez głównego bohatera:

Zaczął lat temu przeszło 20 od studium katastrof kolejowych. Umysł jego bystry a wnikliwy z wrodzoną mu zapalczywością śledził przebieg tych kataklizmów ruchu, wchodził w przyczyny, rozpatrywał przesłanki.

Po pewnym czasie dotarł do wniosku, że po uwzględnieniu ułomności ludzkich zmysłów, fizycznego zmęczenia wskutek przydługiej służby, jako też wadliwości regulaminu i kolejowych urządzeń pozostaje pewna reszta, owo niewyjaśnione nigdy „coś” nie dające się podciągnąć pod żadną kategorię przyczyn i powodów, które wywołały katastrofę [N, s. 108].

\footnotetext{
11 B. Zwolińska, Wampiryzm w literaturze romantycznej i postromantycznej. Na przykładzie "Opowieści niesamowitych" Edgara Allana Poe, "Poganki" Narcyzy Żmichowskiej oraz opowiadań Stefana Grabińskiego, Gdańsk 2002, s. 136.

12 A. Gruszecki, Cygarniczka. Powieść, Stevens Point 1911, s. 31.

13 G. Daniłowski, Pociag, [w:] idem, Nego. Nowele, Warszawa 1899, s. 130.

14 Zob. J. Zych, Rzecz o duchach w Drugiej Rzeczypospolitej czyli Przewodnik po ruchu spirytystycznym oparty na rzetelnych źródłach, Kraków 1999.

15 L. Pułka, M. Kosińska-Pułka, A. Ziółek, Dzikusy Bettelheima, [w:] iidem, Książki i ekrany. Eseje o kulturze popularnej, Wrocław 2005, s. 14.
} 
Badającemu wypadki kolejowe Bytomskiemu zawsze pozostaje „coś”, co nie pozwala do końca wyjaśnić przyczyny katastrof. Podobnie pewien niedosyt pozostawia wyjaśnienie zagadki „psa Baskerville’ów”: „Oto i wszystko, co wiem o tej ciekawej sprawie. Jedno tylko pozostaje do wyjaśnienia: w jaki sposób Stapleton, doszedłszy do sukcesji, byłby wyjaśnił, dlaczego tak długo zamieszkiwał w pobliżu Baskerville-Hall pod przybranym nazwiskiem? W jaki sposób byłby się upomniał o spadek, bez zwrócenia podejrzeń?” - pyta doktor Wat$\operatorname{son}^{16}$. Jest przecież prawdopodobne, że Grabiński znał tłumaczone na język polski lub adaptowane na potrzeby polskiego czytelnika teksty Arthura Conan Doyle'a...

Grabiński pisarz wydaje się zafascynowany narracjami kultury popularnej, i to przede wszystkim w tej odmianie, którą Janusz Dunin charakteryzuje następująco:

[...] istniała i istnieje - częściej zła, niż dobra - rozrywkowa literatura relaksowa, stanowiąca część współczesnej nam kultury masowej - powieści awanturnicze, kowbojskie, sensacyjne, że wymienimy tylko takie nazwiska, jak Karol May, Edgar Wallace, A. Conan Doyle, Agata Christie i wiele innych. W nurcie romansowym tego piśmiennictwa światową klasę reprezentowała Hedwig Courths-Mahler [...]. Ich twórczość, adresowa nie do najwybredniejszego odbiorcy, stanowi jednak część literatury sensu stricto i nie ma przecież nic wspólnego z literaturą kramarską czy brukową.

Charakterystyczną cechą tej twórczości jest i to, że - niezależnie od wszystkich słusznych czy niesłusznych zarzutów, jakie by ją mogły spotkać - reprezentuje ona co najmniej poprawne rzemiosło literackie. $[\ldots]$ Cała ta twórczość $[\ldots]$ jest jeszcze terenem naukowo niezbadanym ${ }^{17}$.

Wampiry, tajemnice techniki i technologii, walka płci, tajemnice jaźni - to tylko niektóre z najchętniej eksploatowanych przez autora Demona ruchu tematów. Ich poruszanie wiąże się z zapewnieniem czytelnikowi silnych przeżyć emocjonalnych, co niewątpliwie jest jednym z celów literatury popularnej ${ }^{18}$. „Literatura popularna bywa bowiem nader często czytywana na zasadzie ucieczki, czyli schowania się w świat niby rzeczywisty, ale przecież inny niż codzienny" - stwierdza Anna Martuszewska ${ }^{19}$. Taki jest świat opowiadań i powieści Grabińskiego: „dziwność”, „niecodzienność” są niejako organicznie wpisane w rzeczywistość powszedniego dnia. „Polski Poe” niezwykle chętnie korzysta z obiegowych, wręcz ogranych już symboli (fatalna trzynastka - N, s. 198-199, 215; trzecia po południu N, s. 25, 376, 454), odwołując się do światopoglądu potocznego. Pólnoc to u Grabińskiego „godzina duchów” (N, s. 216), światem zaś rządzi siła przypadku. To właśnie autor Demona ruchu „do rekwizytorium powieści grozy wprowadził takie motywy, jak upiorny pociąg, wagony przenoszące bohaterów między wymiarami czy nawiedzona stacja kolejowa, sprawnie łącząc je z klasyczną konwencją literatury grozy"20. Truizmem będzie, jeśli przypomnę, że Grabiński nie jest w wyżej wspomnianej fascynacji narracjami popularnymi odosobniony, jeżeli chodzi o pisarzy tworzących w drugiej połowie XIX i na początku XX wieku. Sche-

${ }^{16}$ A. Conan Doyle, Tajemnica Baskerville'ów. Dziwne przygody Sherlocka Holmesa, tłum. E. Żmijewska, Warszawa 1902, s. 179.

17 J. Dunin, Papierowy bandyta. Ksiq̨̇̇ka kramarska i brukowa w Polsce, Łódź 1974, s. 10-11.

18 Jedną z podstawowych funkcji literatury popularnej jest to, że "dostarcza odbiorcy mocnych wrażeń poprzez prezentację tajemniczych i nadzwyczajnych zjawisk, bulwersujących lub przerażających zdarzeń, które stawiają bohatera(ów) w sytuacjach ekstremalnych". G. Legutko, Sacrum w oczach rewolucjonisty. O "Marii Magdalenie" Gustawa Daniłowskiego, Kielce 2005, s. 311.

19 A. Martuszewska, „Ta trzecia”. Problemy literatury popularnej, Gdańsk 1997, s. 24.

20 T. Smejlis, Grabiński Stefan, [hasło w:] SLP, s. 188. 


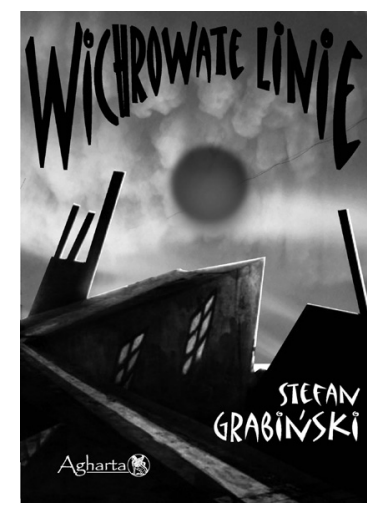

Projekt okładki antologii:

S. Grabiński, Wichrowate linie. (Utwory rozproszone), wstęp i oprac. Jakub Knap, Wydawnictwo Agharta

maty opowiadań autora Salamandry można scharakteryzować słowami Zbigniewa Jarosińskiego, który o sposobie zawiązywania akcji w popularnych powieściach dwudziestolecia międzywojennego pisze: „Inwazja świata niezwykłego w świat codzienny, przecięcie się powszedniości i przygody, zderzenie zbrodni i ładu albo zespalające oba człony opozycji - zakazana miłość, niespodziewana zagadka, podróż stają się początkiem rozwoju fabuły i w jej toku mogą się powtarzać wielokrotnie"21.

Stefan Grabiński najchętniej wykorzystuje w swoich tekstach schemat zagadki, tak charakterystyczny dla opowieści kryminalnej ${ }^{22}$, zapoczątkowanej przecież przez Poego. Jego bohaterowie zwykle wplątani zostają w ciąg tajemniczych zdarzeń, których wątek wspólny próbują - z lepszym czy gorszym skutkiem - zrekonstruować. Eksploatowana przez Grabińskiego narracja pierwszoosobowa sprzyja budowaniu atmosfery niepewności i zagrożenia, czytelnik zostaje „wrzucony” w wir wydarzeń, z których, chcąc nie chcąc, rozumie tylko tyle, ile w danym momencie wie narrator: „Ktoś mnie wypatrzył! Ktoś wytropił!” - takim dramatycznym okrzykiem zaczyna się opowiadanie Saturnin Sektor (N, s. 266). Strukturę kryminału wykorzystuje Grabiński na przykład w opowiadaniu $W$ willi nad morzem, w którym pierwszoosobowy narrator opisuje spotkanie po latach ze znajomym z młodości. Ryszard - wdowiec i ojciec nadwrażliwego Adasia, zarazem pisarz i esteta - okazuje się zabójcą, czego potwierdzeniem jest zastrzelenie się nad grobem kochanka żony. Rolę detektywa gra Bytomski, bohater opowiadania Fałszywy alarm, „detektywem” jest również podmiot opowiadania Problemat Czelawy i narrator Na tropie, który wciąż pyta, dedukuje, domyśla się i podejrzewa: „Powoli poprzez natłok przypuszczeń, kombinacji, domysłów wydarło się silne jak śmierć, nie ukojone pragnienie zwiedzenia miejsca zbrodni. Szalona jakaś ciekawość wlokła na ponury teren nocnego uczynku, pchała do rozpatrzenia sytuacji” - zwierza się czytelnikowi (N, s. 453). U Grabińskiego, nawet kiedy do świata przedstawionego wkracza metafizyka, wcześniej czy później zyskuje to wyjaśnienie. Wbrew pozorom, rzeczywistością tych tekstów rządzi żelazna wręcz (choć bardzo często inna od codziennej) logika. Tego typu dramatyczne, wyraźne zakończenia są dla tekstów Grabińskiego charakterystyczne. Autor Salamandry nigdy nie porzuca fabuły - jest ona jednym z czynników wspomagających tekstowy porządek zdarzeń.

Częstym u Grabińskiego zabiegiem, który lączy jego twórczość z literaturą popularną, jest próba projektowania odbioru tekstu. Służą temu, po pierwsze, podtytuły (np. Powieść fantastyczna). Drugim chwytem charakterystycznym dla narracji popularnych chętnie stosowanym przez Grabińskiego jest aktualizacja (lub iluzja aktualizacji): „Od r. 1880 aż do chwili obecnej naliczył Bytomski 15 takich punktów rozmieszczonych w dwóch zrzeszeniach” (N, s. 111). Z narracjami popularnymi łączy twórczość Grabińskiego także sposób konstruowania postaci. Autor Salamandry często odwoluje się do schematu heros - demon zła (ze wskazaniem zwłaszcza na herosa); taki zabieg konstrukcyjny odnaleźć można na przykład w opowiadaniu Demon ruchu, gdzie narrator tak charakteryzuje bohatera: „w jednym z przedziałów klasy pierwszej, wciśnięty w kąt między ścianą wozu a poduszką oparcia, drzemał mężczyzna przeszło czterdziestoletni, o silnej, herkulicznej budowie ciała" (N, s. 119). Szygoń z tej noweli jest herosem nie tylko fizycznie: „rozumial, że swoje wyjątkowe rekordy odbywał pod wpływem sił kosmicznych, żywiołowych, dla których realiza-

${ }^{21}$ Z. Jarosiński, op. cit., s. 22.

22 E. Kuźma, op. cit., s. 322 pisze o zagadce kryminalnej jako o jednym ze stereotypów wytworzonych przez gatunki kultury popularnej. 
cja w formie jazdy kolejowej była dziecinnym kompromisem, wywołanym przez warunki terenu i ziemskiego środowiska" (N, s. 124). Znamienne wreszcie, że zbiór Niesamowita opowieść ukazał się w 1922 roku w Wydawnictwie Dzieł Pogodnych...

Grabiński bardzo chętnie odnosi się w swoich tekstach do egzotycznych realiów, używa wyszukanego słownictwa. Nadekspresyjny miejscami styl przypominać może epigonów młodopolskiego stylu. „Rozdarł kiry nocy purpurowy finał Grota” - czytamy w zakończeniu Maszynisty Grota (N, s. 147). Podobna „nadekspresyjność” cechuje niektóre opisy przyrody, np. W willi nad morzem (N, s. 52).

Charakterystyczne dla autora Problematu Czelawy jest również posługiwanie się czasoprzestrzenią awanturniczą ${ }^{23}$. Tak jest na przykład w opowiadaniu Głucha przestrzeń, w którym „królestwo” Wawery opisał narrator za pomocą takich określeń, jak: bagnisty teren, malaryczna okolica, równina pokryta bujną zielonością, „głucha przestrzeń”, zamknięta i izolowana (N, s. 77). Krytycy zarzucali Grabińskiemu uproszczoną psychologię postaci; to również, jak sądzę, konsekwencja fascynacji narracjami popularnymi, w których drobiazgowa analiza osobowościowa jest o wiele mniej istotna dla struktury tekstu niż „wciągająca” fabuła. Uproszczenie rysunku psychologicznego jest chwytem mającym potęgować w odbiorcy poczucie niepokoju czy wręcz grozy - bohater zaledwie naszkicowany jest jednocześnie bardziej uniwersalny, co sugeruje, że jego perypetie mogą stać się udziałem każdego. Uproszczenie wiąże się również z charakterystyczną dla tekstu popularnego „regułą synonimiczności”, w myśl której „poszczególne wydarzenia, działania, rekwizyty składają się w wyodrębnione ciągi znaków połączonych więzią harmonii i dopasowania, pozostających w relacji wzajemnego uzupełniania się i powtarzania tych samych sensów" ${ }^{\prime 2}$. W wypadku twórczości Grabińskiego regułę synonimiczności widać przede wszystkim w skupieniu poszczególnych zbiorów jego opowiadań wokół pewnych tematów: Demon ruchu traktuje o ruchu i kolei, podobnie skupiona wokół tytułowego motywu jest Księga ognia. Autor Kochanki Szamoty posługuje się też figurami charakterystycznymi dla modernistycznego oglądu świata: w Głuchej przestrzeni mamy np. „człeka - tułacza wieczystego” i scenę „nowoczesnej” śmierci pod kołami pociągu ${ }^{25}$. Jest dla mnie bowiem „polski Poe” przede wszystkim pisarzem XIX-wiecznym, niezależnie od tego, że znaczna część jego twórczości powstała już w dwudziestoleciu międzywojennym. Uproszczonej psychologii upatrywałabym również w posługiwaniu się przez Grabińskiego motywem sobowtóra (Problemat Czelawy): Doktor Jekyll i Mr Hyde autora Salamandry dzieli osobowość głównego bohatera na stronę „jasną” i „ciemną” (niezależnie od tego, że „sobowtór” okazuje się w istocie bratem bohatera: Grabiński tak konstruuje opowiadanie, że czytelnik długo nie ma pewności, czy profesor nie cierpi na rozdwojenie jaźni). „Po okresie sztuki realistycznej, zrównoważonej, zamkniętej w bezpiecznym kręgu doświadczeń powszechnych i powszednich, budzi się głód wrażeń niezwykłych, ekscytujących imaginację i nerwy" - pisał Artur Hutnikiewcz - a ten „głód” jest szczególnie widoczny w wypadku tekstów, w których wykorzystano elementy

23 T. Żabski, Czasoprzestrzeń awanturnicza, [hasło w:] SLP, s. 94-95.

24 Z. Jarosiński, op. cit., s. 20.

${ }^{25}$ Choć opisanej w sposób metaforyczny: po Wawerę przyjeżdża wypełniony przyjaznymi mu ludźmi pociąg, który „ruszył z przeciągłym gwizdem i potoczył się w przestrzeń”; nazajutrz bohater zostaje znaleziony zamarznięty (N, s. 90). Zmetaforyzowane wizje śmierci pod kołami pociągu odnajdujemy w wielu powieściach powstałych w drugiej połowie XIX i na początku XX wieku, zarówno wysokoartystycznych, jak i popularnych. Za taką „symboliczną” śmierć możemy uznać np. próbę samobójstwa Wokulskiego w Lalce; pod kołami lokomotywy ginie Jaskółka, tytułowa bohaterka powieści Gustawa Daniłowskiego.

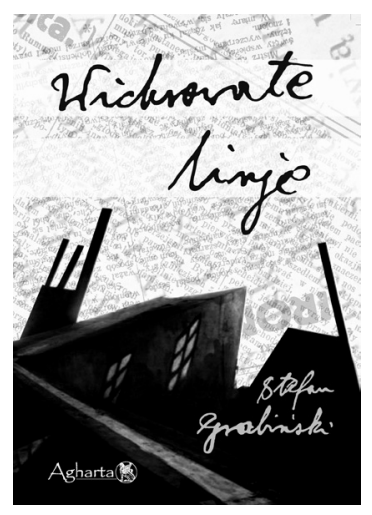

Ostateczna wersja okładki antologii: S. Grabiński, Wichrowate linie. (Utwory rozproszone), wstęp i oprac. Jakub Knap, Wydawnictwo Agharta, Kraków 2012 


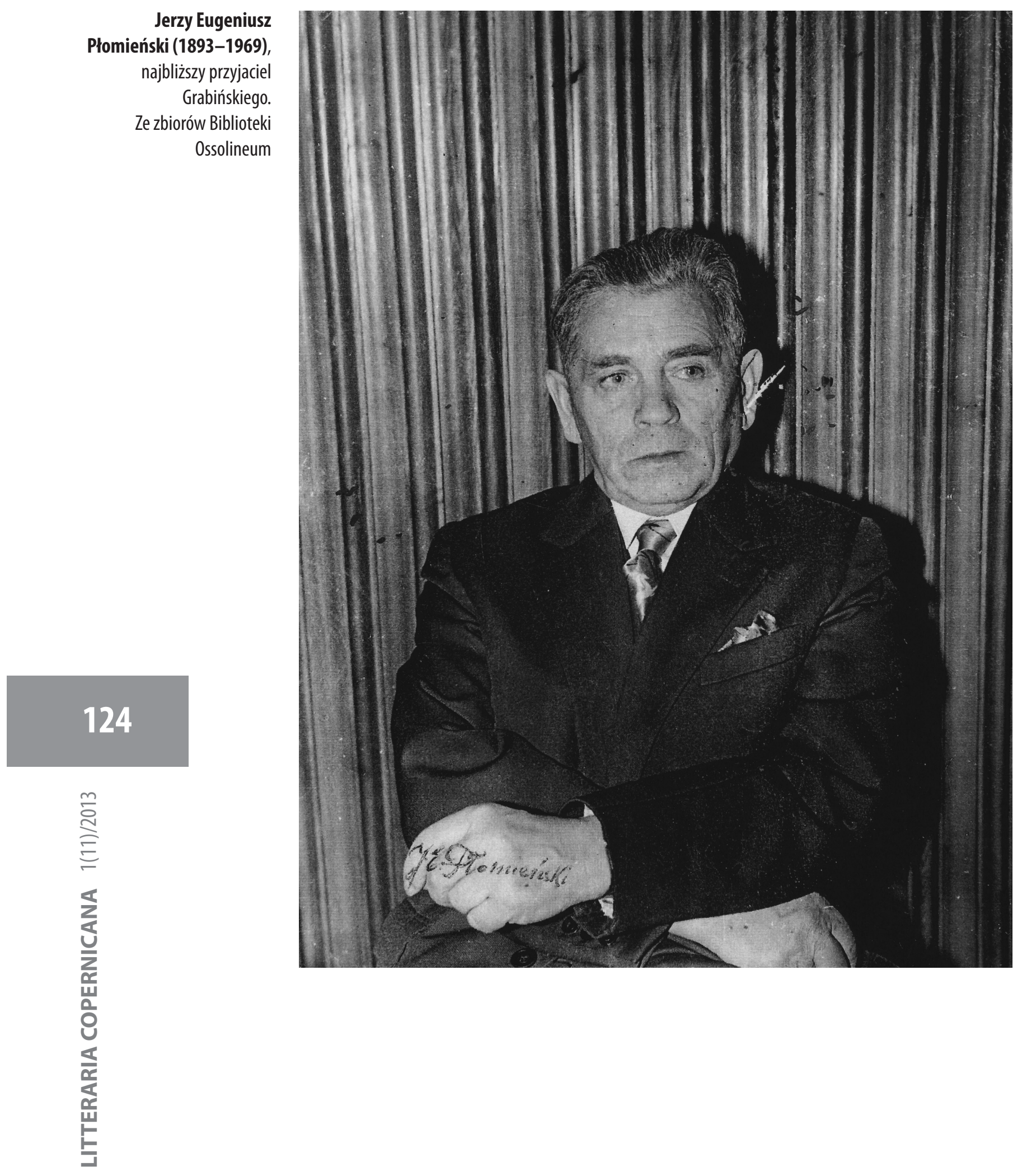


fantastyki lub grozy (TLSG, s. 36). Zarzucano Grabińskiemu „niebezpieczną skłonność do ulegania pewnym nawykom, przez samego pisarza wypracowanym szablonom, ową inercję wyobraźni” (TLSG, s. 85). Nie sposób się z tym nie zgodzić: bohaterowie Grabińskiego bowiem to bardzo często „figury” w znaczeniu zaproponowanym przez Johna Harveya, cechujące się „względną niezmiennością połączoną ze szczególnym rodzajem swobody”" postaci zwykle są „szarymi”, przeciętnymi ludźmi, kryjącymi w sobie drugą, mroczną lub pod jakimś względem tajemniczą stronę osobowości, którą w toku rozwoju fabuły poznają.

Osobnym problemem jest zagadnienie oryginalności artystycznej prozy Grabińskiego. Hutnikiewicz zwraca uwagę na „zjawiskowość, pierwszość i osobność” twórczości pisarza (TLSG, s. 9). Nie możemy jednak zapominać, że autor zawsze jest zanurzony w tym, co określić można jako „osocze kulturowe”. Choć jest to truizm, to warto przypomnieć, że najbardziej odosobniony z pozoru twórca działa, porusza się w pewnej przestrzeni społecznej i artystycznej - miał tę świadomość i autor Cienia Bafometa (TLSG, s. 10). Oryginalność twórcza oraz sięganie do chwytów charakterystycznych dla pisarstwa popularnego oczywiście się nie wykluczają - metaforą postawy Grabińskiego mógłby być, jak sądzę, cytat z noweli Zez: „Byłem zagorzałym wielbicielem wszystkiego, co osobiste, oryginalne, jedyne, w sobie zamknięte - Brzechwa, przeciwnie, szydził z wszelkiego indywidualizmu, uważając go za chimerę zarozumiałych półgłówków; stąd nie wierzył w żadną inwencję, pomysłowość, sprowadzając je do wykładników wpływów środowiska, rasy, tzw. ducha czasu" (N, s. 40).

Fascynacja narracjami popularnymi od czasu wykrystalizowania się obiegów literackich (a więc narodzin kultury masowej w drugiej połowie XIX wieku) jest widoczna w twórczości wielu wybitnych pisarzy - wystarczy przywołać chociażby Dzieje grzechu Stefana Żeromskiego czy Wampira Władysława Stanisława Reymonta; teksty Grabińskiego są, moim zdaniem, równie mocno zorientowane na wykorzystywanie konwencji literatury popularnej, jak na przykład powieści czy opowiadania Gustawa Daniłowskiego.

Jakie korzyści może przynieść analiza związków twórczości Grabińskiego z literaturą popularną? Przede wszystkim wyrywa pisarstwo autora Wyspy Itongo z kręgu czytelniczego niezrozumienia; inna jest przecież poetyka odbioru tekstu popularnego, inaczej czytamy teksty wysokoartystyczne - najtrudniej jest mówić o twórczości „pomiędzy”, dlatego warto badać kolejne możliwości interpretacyjne tekstów w jakiś sposób niejednoznacznych, nie przywiązując się jednakże zbytnio do żadnej ścieżki odczytań. Takie postępowanie badawcze pozwala także zrozumieć, że Grabiński nie do końca był pisarzem „osobnym” zdecydowanie łatwiej mówić o jego twórczości, gdy zauważymy, że „tekstowy świat” jego utworów nie ogranicza się jedynie do fascynacji Edgarem Allanem Poe. Po trzecie wreszcie: przyjęta przeze mnie strategia badawcza pokazuje, że „linie odgraniczające literaturę popularną od twórczości wysokiej są [... ] nieostre”, ponieważ „literatura popularna często wchodzi w kontakt $\mathrm{z}$ wysokoartystyczną i ludową poprzez wykorzystanie ich dorobku oraz oferowanie własnych rozwiązań; stwarza pogranicze, na którym przynależność niektórych odmian (np. powieść historyczna, literatura fantastyczna) staje się problematyczna”27.

\footnotetext{
${ }^{26}$ W. J. Harvey, Stosunki międzyosobowe w powieści, tłum. I. Sieradzki, „Pamiętnik Literacki” 1971, z. 1, s. 253.

27 G. Legutko, op. cit., s. 311.
} 